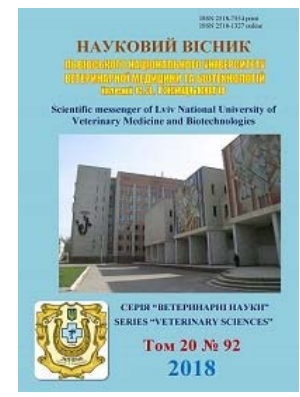

\author{
Науковий вісник Дьвівського національного університету \\ ветеринарної медицини та біотехнологій імені С.3. Гжицького
}

\author{
Scientific Messenger of Lviv National University \\ of Veterinary Medicine and Biotechnologies
}

UDC 636:612.015.6:636.2.084.55

\title{
Influence of the hormonal background on the morphological replacement piglets
}

\author{
I.I. Stupar
}

Poltava State Agrarian Academy, Poltava, Ukraine

Article info

Received 28.10.2018

Received in revised form 29.11.2018

Accepted 30.11.2018

Poltava State Agrarian Academy, Skovorody Str., 1/3, Poltava, 36003, Ukraine.

Tel $:+38-067-128-46-31$

E-mail:Intern-fvm@meta.ua
Stupar, I.I. (2018). Influence of the hormonal background on the morphological replacement piglets. Scientific Messenger of Lviv National University of Veterinary Medicine and Biotechnologies, 20(92), 172-177. doi: 10.32718/nvlvet9236

The puberty period in pigs depends on the functional activity of the endocrine system, which has an effect on the blood through the connective tissue. It has been established that steroid and thyroid hormones regulate the processes of metabolism and proliferation, differentiation and apoptosis of cells. The aim of the research was to establish the peculiarities of formation of the morphological composition of blood under the influence of steroid and thyroid hormones in the process of puberty in different directions of productivity in the pigs. Experiments were performed on two groups of clinically healthy pigs of Pietrain breed and Large White breed. To assess the hormonal and morphological blood was taken from pigs from the anterior hollow vein in the 4-, 5-.6-, 7-month-old age (when their live weight reaches $100 \mathrm{~kg}$ ). The predominance of hemoglobin content and the amount of erythrocytes in the blood of piglets of Pietrain breed over a Large White breed on the 120-150th day of development $(P<0.05)$ was observed, against the background of the general decrease in leukocytes in pigs of both breeds at the age of 5 months with the next gradual increase. The age-related changes in the leukocyte formula were directly related to the direction of animal productivity. In the Large White breed, from the beginning of the experiment, there was an increase in the number of rodenuclear neutrophils to 210-day-olds, followed by a sharp decreasing on 36.4\%. In Pietrain breed, the level of the rodenuclear neutrophils decreased on $28.6 \%(P<0.01)$ at the age of 5 months, followed by a sharp increasing over the coming months. From the 5th to the 7th months of the development of animals, the concentration of estradiol decreased in the first genotype 2 times $(P<0.05)$; in the second genotype -1.9 times $(P<0.01)$. The content of thyroxine and triiodothyronine increased in the blood serum in Pietrain breed pigs $(P<0.01)$ and Large White breed $(P<0.001)$ in the period from 120th to 180th day of development. It was found that the amount of progesterone in Large White breed was higher relatively to Pietrain breed in all investigated periods. The content of estradiol in pigs of both breeds from the 120th and the 150th day of development tended to decrease - by 2.8 times $(P<0.001)$ in Large White breed, 1.4 times $(P<0.05)$ in Pietrain breed, and testosterone increases, respectively, $2.1(P<0.05)$ and $1.9(P<0.05)$ times. The significant influence of progesterone on the number of lymphocytes and common leukocytes in Pietrain breed pigs was established. The level of estradiol significantly influenced the number of granulocytes in Pietrain breed pigs at the age of 5 months $(r=0.92 \ldots 0.99)$, and in animals of Large White breed the maximum correlation level was observed at the achievement of the 150th $(r=0.61)$ and 180 days of development $(r=0.94)$.

Key words: pigs, progesterone, estradiol, testosterone, hemopoiesis.

\section{ВПлив гормонального фону на морфологічний склад крові у ремонтних свинок}

\author{
I.I. Ступарь
}

Полтавська державна аграрна академія, м. Полтава, Украӥна

Пубертатний період розвитку свинок залежить від функиіональної активності ендокринної системи, яка здійснює вплив на кров через сполучну тканину. Встановлено, щзо стероїдні та тироїдні гормони регулюють процеси метаболізму $і$ проліферації, диференціації $i$ апоптозу клітин. Метою досліджень було встановити у свинок різних напрямів продуктивності особливості 
формування морфологічного складу крові під впливом стероїдних та тироїдних гормонів в процесі статевого дозрівання. Експеримент виконано на двох групах клінічно здорових свинок порід велика біла та п'єтрен. Для оцінки гормонального і морфологічного статусу кров у свиней відбирали з передньої порожнистої вени у 4-, 5-, 6-, 7-місячному вічі (при досягненні їх жсвої маси 100 кг). Встановлено переважання вмісту гемоглобіну та кількості еритроцитів у крові свинок породи п'єтрен над великою білою на 120 150-ту доби розвитку $(P<0,05)$, на тлі загального зниження лейкочитів у свинок обох порід у 5-місячному вічі з наступним поступовим збільшенням. Вікові зміни лейкоцитарної формули перебували в прямій залежності від напряму продуктивності тварин. У великої білої породи від початку експерименту відбувалося збільшення кількості паличкоядерних нейтрофілів до 210 -денного віку з наступним різким зменшенням на 36,4\%. У свинок породи п'єтрен рівень паличкоядерних нейтрофілів знизився на 28,6\% (P < 0,01) у віці 5-ти місяџів з наступним різким підвищенням протягом послідуючих місяців. Виявлено, щзо кількість прогестерону у свинок великої білої породи була вищою відносно n'єтрен в усі досліджувані періоди. Вміст естрадіолу у свинок обох порід від 120-і до 150-ї діб розвитку мав тендениію до зниження - у 2,8 разів $(P<0,001)$ у великої білої породи, в 1,4 рази $(P<0,05)$ у п'єтрен, а тестостерону зростає відповідно 2,1 (P<0,05) i 1,9 $(P<0,05)$ разів. 3 5-го по 7-ий місяці розвитку тварин концентрація останнього знизилась у першого генотипу у 2 рази $(P<0,05) ;$ у другого - 1,9 рази $(P<0,01)$. Вміст тироксину та трийодтироніну зростав в сироватиі крові у свинок порід n’єтрен $(P<0,01)$ та велика біла $(P<0,001)$ в період від 120-ї до 180-ї діб розвитку. Встановлено істотний вплив прогестерону у свинок породи п'єтрен на кількість лімфоцитів та загальних лейкоцитів. Рівень естрадіолу суттєво впливав кількість гранулоцитів у свинок породи п'єтрен у 5-місячному віці (r = 0,92...0,99), а у тварин великої білої породи максимальний рівень кореляції був відмічений досягненні 150-ї $(r=0,61)$ та 180-ї діб розвитку (r = 0,94).

Ключові слова: свинки, прогестерон, естрадіол, тестостерон, гемопоез.

\section{Вступ}

Пубертатний період розвитку свинок залежить від функціональної активності ендокринної системи, яка здійснює вплив на кров через сполучну тканину (Girard et al., 1994; Whittle et al., 2001). Встановлено, що стероїдні та тироїдні гормони регулюють анаболічні й катаболічні механізми обміну речовин, процеси проліферації, диференціації і апоптозу клітин. Однак, роль цих речовин в регуляції гемопоезу у постнатальному періоді розвитку тварин з'ясована неповністю. Тироксин і трийодтиронін функціонують також і в клітинах системи гемопоезу, однак вікові особливості процесу конверсії, як і функціональні властивості цих речовин у клітинах кісткового мозку і крові тварин, не досліджені. Про те, ще залишаються недостатньо вивченими й механізми впливу проегестерону та естрогену, андрогенів на процеси еритро- та лейкопоезу (Köhrle, 2000; Bianco et al., 2002).

Аналіз літературних джерел. Важливим життєвим середовищем для всіх клітин, тканин і органів тварин $\epsilon$ кров, яка транспортуючи біологічно активні речовини, регулює обмін гормонів, рівновагу електролітів, забезпечує відповідну функціональну активність організму в умовах ендогенних і екзогенних чинників. Дана тканина, підтримуючи гомеостаз, являє собою лабільну систему, відображаючи тим самим метаболічні процеси, що протікають в організмі. Однак мінливість морфологічного і біохімічного складу крові знаходиться в певних межах, які $є$ фізіологічною нормою для кожного виду тварин (Salomatin et al., 2010).

У регуляції еритро- та лейкопоезу провідна роль належить гормонам, які беручи участь у паракринних та аутокринних механізмах регуляції метаболізму в клітинах, визначають їх здатність до проліферації, диференціації, апоптозу, адгезії, міграції (Majka et al., 2001). Зміни в системі кровотворення, що відбуваються у свинок під час перинатального розвитку та перебудова регуляторних механізмів гемопоезу при переході до постнатального періоду життя відіграють провідну роль у визначенні функціональної активності клітин крові та імунної системи не лише відразу після народження, але і в подальші вікові періоди онтогенезу. Дослідженнями (Antonyak, 2002; Pinto et al., 2012) встановлено окремі зміни кровотворних та лімфоїдних органів в процесі ембріонального та постембріонального розвитку. При цьому залишаються нерозкритими особливості роботи органів кровотворення в процесі статевого дозрівання у свиней різних напрямів продуктивності.

Метою досліджень було встановити у свинок різних напрямів продуктивності особливості формування морфологічного складу крові під впливом стероїдних та тироїдних гормонів в процесі статевого дозрівання.

Для вирішення даної проблеми були поставлені наступні завдання:

1. Дослідити вікові зміни морфологічного складу крові у ремонтних свинок у період від 120-ї до 210-ї діб розвитку.

2. Встановити динаміку вмісту стероїдних і тироїдних гормонів у свинок в пубертатний період.

3. Проаналізувати ступінь взаємозв'язку гормонів (тестостерон,прогестерон, естрадіол, тироксин та трийодтиронін) 3 морфологічним складом крові свинок.

\section{Матеріал та методи досліджень}

Експеримент проведено на клінічно здорових свинках відібраних за принципом аналогів, з яких сформовано дві дослідні групи по 5 голів у кожній: I група - тварини породи п’єтрен та II група - тварини породи велика біла. Годівля тварин здійснювалась згідно кормових норм Інституту свинарства і АПВ НААН. Для оцінки гормонального та морфологічного статусу кров для досліджень від свиней відбирали з передньої порожнистої вени в 4-, 5-, 6-, 7-місячному віці (при досягненні їх живої маси 100 кг). Вміст тестостерону, прогестерону, естрадіолу, тироксину і трийодтироніну у сироватці крові визначали методом електрохемілюмінісцентногоімуноаналізу "ECLIA" на автоматичному аналізаторі системи Elecsys 2010 (RocheDiagnosticsGMBH, Німеччина).

Кількість еритроцитів і лейкоцитів визначали за допомогою мікроскопа в камері з сіткою Горяєва за 
методом П'ятницького, лейкограму - у мазках, пофарбованих за Романовським-Гімза. Кількість гемоглобіну визначали гемоглобінціанідним методом фотоелектроколориметрично. Швидкість осідання еритроцитів визначали за методом Панченкова (Ionov et al., 1952; Kozlovskaja and Martynova, 1975; Simonjan and Hisamutdinov, 1995; Levchenko et al., 2004; Kondrahin et al., 2004; Gorjachkovskij, 2005).

Отриманий цифровий матеріал був статистично опрацьований за допомогою програми Statistika для Windows XP. Для порівняння досліджуваних показників та їхніх між групових різниць використовували Т - критерій Стьюдента, а результат вважали вірогід- ним після $\mathrm{P}<0,05$. У таблицях прийняті такі умовні позначення :* $-\mathrm{P}<0,05, * *-\mathrm{P}<0,01, * * *-\mathrm{P}<0,001$.

\section{Результати та їх обговорення}

Дані експерименту свідчать про те, що кількість еритроцитів та гемоглобіну у свинок знижувались від 3-х до 7-місячного віку При цьому вміст останнього у свиней великої білої породи в цілому був нижчим відносно породи п'єтрен, де максимальну міжпорідну різницю встановлено на 120 добу - 16\% (Р < 0,05) (табл. 1).

\section{Таблиця 1}

Морфологічні та гормональні показники крові у свинок різних порід впродовж статевого дозрівання, $\mathrm{M} \pm \mathrm{m}, \mathrm{n}=$

5

\begin{tabular}{|c|c|c|c|c|}
\hline \multirow{2}{*}{ Гематологічні показники } & \multicolumn{4}{|c|}{ Вік тварин, доби } \\
\hline & 120 & 150 & 180 & 210 \\
\hline \multicolumn{5}{|c|}{ Порода п’єтрен } \\
\hline Гемоглобін, г/л & $115,64 \pm 1,87$ & $110,71 \pm 1,35 *$ & $95,92 \pm 1,08$ & $87,63 \pm 2,07$ \\
\hline Еритроцити,Т/л & $8,82 \pm 0,17$ & $8,67 \pm 0,35^{*}$ & $6,82 \pm 0,11$ & $6,12 \pm 0,34$ \\
\hline Лейкоцити, Г/л & $12,74 \pm 1,99$ & $10,16 \pm 1,15$ & $10,24 \pm 1,54$ & $11,96 \pm 2,18$ \\
\hline Еозинофіли,\% & $2,4 \pm 0,89$ & $2,6 \pm 0,89$ & $2,2 \pm 0,83$ & $2,8 \pm 0,84$ \\
\hline Юні,\% & 0,8 & 0,8 & 0,6 & 1,2 \\
\hline Паличкоядерні,\% & $2,2 \pm 0,44$ & $2,6 \pm 0,89$ & $3,0 \pm 1,0$ & $2,2 \pm 0,84$ \\
\hline Сегментоядерні,\% & $44,0 \pm 2,24$ & $43,2 \pm 3,03$ & $45,6 \pm 3,21$ & $45,0 \pm 4,30$ \\
\hline Лімфоцити, \% & $47,8 \pm 4,6$ & $46,4 \pm 1,82$ & $43,0 \pm 4,64$ & $45,4 \pm 4,72$ \\
\hline Моноцити, \% & $2,6 \pm 1,14$ & $3,8 \pm 1,79$ & $5,0 \pm 0,71$ & $2,6 \pm 1,52$ \\
\hline ШОЕ,мм & $3,6 \pm 1,51$ & $4,6 \pm 2,70$ & $3,8 \pm 1,92$ & $3,2 \pm 1,30$ \\
\hline Прогестерон, нмоль/л & $14,96 \pm 2,53$ & $10,89 \pm 2,44$ & $12,63 \pm 2,01$ & $15,92 \pm 1,56$ \\
\hline Естрадіол, нмоль/л & $19,12 \pm 1,56$ & $13,51 \pm 1,74$ & $8,11 \pm 1,11$ & $9,56 \pm 1,15$ \\
\hline Тестостерон, нмоль/л & $0,047 \pm 0,004$ & $0,092 \pm 0,0063^{*}$ & $0,070 \pm 0,006$ & $0,048 \pm 0,002 *$ \\
\hline Тироксин, нмоль/л & $45,97 \pm 3,61$ & $75,21 \pm 5,45$ & $90,12 \pm 9,11 * * *$ & $66,18 \pm 4,48$ \\
\hline Трийодтиронін, нмоль/л & $2,65 \pm 0,11$ & $2,45 \pm 0,62$ & $3,03 \pm 0,07$ & $1,39 \pm 0,12$ \\
\hline \multicolumn{5}{|c|}{ Порода велика біла } \\
\hline Гемоглобін,Г/л & $99,7 \pm 5,29$ & $94,8 \pm 3,13$ & $84,5 \pm 3.92$ & $78,7 \pm 5,12$ \\
\hline Еритроцити,Т/л & $7,81 \pm 0,32$ & $6,35 \pm 0,37$ & $6,81 \pm 0,56$ & $6,23 \pm 0,17$ \\
\hline Лейкоцити, Г/л & $11,16 \pm 1,66$ & $9,56 \pm 0,63$ & $11,96 \pm 0,88$ & $13,91 \pm 2,40$ \\
\hline Еозинофіли,\% & $2,4 \pm 1,14$ & $2,0 \pm 0,70$ & $1,8 \pm 1,30$ & $3,0 \pm 1,0$ \\
\hline Юні,\% & 0,6 & 1,2 & 0,4 & 0,6 \\
\hline Паличкоядерні,\% & $2,8 \pm 0,84$ & $2,0 \pm 0,70$ & $2,4 \pm 1,14$ & $2,6 \pm 0,89$ \\
\hline Сегментоядерні,\% & $44,0 \pm 2,65$ & $41,2 \pm 1,92$ & $44,6 \pm 3,44$ & $46,4 \pm 4,67$ \\
\hline Лімфоцити,\% & $46,6 \pm 4,51$ & $49,8 \pm 3,34$ & $45,8 \pm 3,70$ & $42,6 \pm 7,83$ \\
\hline Моноцити, \% & $3,2 \pm 1,0$ & $3,2 \pm 1,79$ & $4,2 \pm 1,48$ & $4,2 \pm 1,92$ \\
\hline ШОЕ,мм & $4,4 \pm 2,30$ & $5,0 \pm 1,58$ & $5,2 \pm 1,48$ & $4,4 \pm 2,32$ \\
\hline Прогестерон, нмоль/л & $12,21 \pm 1,30$ & $16,37 \pm 1,85$ & $15,12 \pm 3,24$ & $27,26 \pm 2,01 * * *$ \\
\hline Естрадіол, нмоль/л & $26,63 \pm 1,58$ & $9,47 \pm 1,28 * * *$ & $24,66 \pm 3,17$ & $11,33 \pm 3,03$ \\
\hline Тестостерон, нмоль/л & $0,036 \pm 0,006$ & $0,077 \pm 0,012 *$ & $0,037 \pm 0,005$ & $0,039 \pm 0,003 * *$ \\
\hline Тироксин, нмоль/л & $56,04 \pm 4,10$ & $93,56 \pm 7,88$ & $131,15 \pm 13,24 * *$ & $103,35 \pm 9,48$ \\
\hline Трийодтиронін, нмоль/л & $3,01 \pm 0,13$ & $3,35 \pm 0,30$ & $3,08 \pm 0,27$ & $2,35 \pm 0,11$ \\
\hline
\end{tabular}

Примітка: * $-\mathrm{P}<0,05 ; * *-\mathrm{P}<0,01 ; * * *-\mathrm{P}<0,001-$ порівняно 3 120-ю добою розвитку

Порівнюючи гематологічні показники крові тварин обох груп було відмічено, що кількість еритроцитів у крові свинок породи п’єтрен у віці 120 днів була вищою на $17 \%(\mathrm{P}<0,05)$ відносно великої білої породи (Vognivenko et al., 2015).

Результати досліджень кількості лейкоцитів у крові свинок впродовж п'ятого місяця розвитку свідчать про суттєве їх зниження відносно з 120-ої доби у породи п’єтрен на 20,3\%, у великої білої на $14,3 \%$. Встановлено, що з 180-ї по 210-у доби вміст лейкоци- тів у цій тканині свинок першого генотипу був майже сталим. Концентрація лейкоцитів у ровесників великої білої породи мала близьку динаміку, перевищуючи відповідні показники породи п’єтрен на 180-ту добу на14,4\%, 210-ту добу на 14,0\%.

Лейкоцитарна формула мала у кожної породи окремі особливості (Guczol and Bilyavceva, 2016). Так у п'єтрен протягом п'ятого і шостого місяців розвитку відбувалося збільшення кількості паличкоядерних нейтрофілів 3 наступним різким зменшенням до 210-ї 
доби на 36,4\%, у той же час сегментоядерні нейтрофіли не мали суттєвих змін. У свинок великої білої породи на 150-ту добу рівень паличкоядерних та сегментоядерних нейтрофілів знизився на $28,6 \%$ (P < $0,01)$ і $6,4 \%$, з наступним підвищенням до 210-ї доби на 30,0 і $12,6 \%$.

Породний фактор мав суттєвий вплив на динаміку кількості лімфоцитів у досліджуваних порід. Так у свинок породи п'єтрен їх вміст поступово знижувався з 4-го по 6-й місяць постнатального розвитку, з незначним підвищенням на 210-ту добу. В той час у тварин великої білої породи максимальна кількість лімфоцитів спостерігалась у 5-ти місячному віці з подальшим різким зменшенням на $14,5 \%$ по досягненні ними 7 ми місячного віку.

Виявлено різке збільшення кількості моноцитів у крові тварин породи п'єтрен майже у 2 рази у 180денному віці, у великої білої лише в 1,3 рази відносно 120-ї доби.

Показники швидкості осідання еритроцитів у першого генотипу були максимального значення у 4місячному віці, у другого - у 5-місячному віці з переважанням у представників великої білої породи, де максимальна міжпорідна різниця виявлена на 180 добу і складала 26,9\%.

Отримані дані досліджень морфологічного складу крові свинок різних порід протягом дослідного періоду динамічно змінювались, що, очевидно, обумовлено фізіологічними змінами у різні періоди їх статевого дозрівання (Rassolov et al., 2014). Такі зміни гематологічного профілю в інтенсивноростучих тварин очевидно обумовлені коливанням інших біологічно активних речовин, особливо гормонів. Коливання рівня останніх може супроводжуватись змінами властивостей еритроцитів та активності лейкоцитів (Köhrle, 2000; Majka et al., 2001; Bianco et al., 2002; Nandi and Rani, 2015).

У проведених нами дослідженнях встановлено, що рівень гормонів у сироватці крові свинок за час статевого дозрівання у різних порід мав відмінні числові діапазони. Уміст прогестерону у свинок породи п’єтрен мав незначні коливання від 3- до 7-місячного віку, досягаючи максимуму на 210-ту добу. Однак у тварин великої білої породи спостерігалась аналогічна закономірність до 180 доби розвитку з послідуючим різким підвищенням концентрації майже на $80 \%$ (Р < 0,001). Кількість естрадіолу у тварин досліджуваних порід була найбільшою у 120-денному віці. Різке послідуюче зниження цього метаболіту, майже у 3 рази (Р < 0,001), відмічено у великої білої на 150-ту добу, а при досягненні тваринами маси 100 кг (180-та доба) кількість його стрімко зростала. Аналогічні коливання, але незначного діапазону, були відмічені у свиней породи п'єтрен.

Концентрація тестостерону у сироватці крові в обох групах досліджуваних тварин від 120- ї до 150-і діб різко збільшилась у 2 рази $(\mathrm{P}<0,05)$. В подальшому його рівень у великої білої породи різко знизився до показників початкового періоду досліджень. У свинок породи п’єтрен кількість даного гормону у аналогічний період поступово знижувалась. Найбільшу міжпорідну різницю між показниками даного гормону встановлено на 180 добу - 52\% (Р <0,05).

Визначення вмісту тироксину в сироватці крові досліджуваних тварин показало значну різницю в кінетиці цих показників у тварин різних порід. У свинок великої білої породи виявлено зростання цього гормону в інтервалі часу з 4 по 6 місяці у 2,3 рази $(\mathrm{P}<$ $0,01)$ із послідуючим зменшенням. Відповідна тенденція зростання концентрації тироксину упродовж від 4 до 6 місяців спостерігалась і у свинок породи п`єтрен - майже у 2 рази $(\mathrm{P}<0,001) 3$ наступним зниженням. Слід зауважити, що рівень тироксину в крові тварин обох порід збільшувався з віком, однак показники були значно вищими у свинок великої білої породи. Найбільшу міжпорідну різницю між рівнями даного гормону встановлено на 180 добу - 45\% (P < $0,05)$ на користь свиней великої білої породи. У сироватці крові свинок великої білої породи найвища концентрація тироксину спостерігалася у 6-місячному віці 3 послідуючим зниженням на $21 \%$ до закінчення 7 місяця постнатального розвитку.

Встановлено, що концентрація трийодтироніну у сироватці крові в обох групах досліджуваних свинок була значно нижчою ніж тироксину. У тварин великої білої породи його вміст становив 2,35-3,01 нмоль/л, у свинок породи п'єтрен 1,39-2,65 нмоль/л. В процесі фізіологічного розвитку тварин динаміка трийодтироніну була близькою до встановленої за рівнем тироксину.

У свинок породи велика біла максимальна концентрація трийодтироніну відмічалася в 150-денному віці. У свинок породи п’єтрен найвища кількість встановлена 180 добу розвитку. Крім того, можна зробити висновок, що тироксин має депонуючу функцію, оскільки знаходиться в організмі у значно більшій кількості (Golikov et al., 1991).

Незважаючи на те, що концентрація $\mathrm{T}_{4}$ більша в десятки разів від $\mathrm{T}_{3}$, динаміка вмісту першого аналогічна другому, це свідчить про те, що трийодтиронін $€$ активною формою, а тироксин запасною, тому коливання рівня естрогенів у сироватці крові свинок в період статевого дозрівання першочергово впливає на рівень Т (Mosin and Ptashkin, 1984; Golikov et al., 1991).

Результати досліджень із впливу гормонів на стан клітин крові отримані на різних видах тварин, свідчать про існування залежності активності еритроцитів та окремих груп лейкоцитів від кількості стероїдів протягом сталого статевого циклу та вагітності (SalakJohnson et al., 1996; Davis et al., 2008).

Для з'ясування впливу змін гормонального фону на морфологічний склад крові у свинок в період становлення статевої функції було розраховано кореляційні взаємозв'язки. Так, у тварин породи п'єтрен вміст прогестерону у 120-денному віці істотно впливав на кількість лімфоцитів $(\mathrm{r}=0,78)$, а в період 3150 ї по 180-ту доби на загальну кількість лейкоцитів (r = 0,60). У свинок великої білої породи даний гормон у відповідний віковий період більш тісно корелював із 
вмістом лейкоцитів $(\mathrm{r}=0,73)$. А у віці 150-ти днів підвищення прогестерону суттєво вплинуло на зниження кількості паличкоядерних нейтрофілів ( $\mathrm{r}=$ 0,51), що підтверджується дослідженнями Shilpa Nandi та Reshma Rani (Nandi and Rani, 2015). У представників породи п’єтрен у 210-му віці прогестерон тісно корелював 3 вмістом гемоглобіну $(\mathrm{r}=0,76)$ та швидкістю осідання еритроцитів $(\mathrm{r}=0,62)$, сила даних зв'язків була вищою у свинок великої білої породи $\mathrm{r}=$ 0,95 i r $=0,68$.

У нашому дослідженні спостерігається посилення взаємозв'язку концентрації естрогену зі збільшенням субпопуляцій гранулоцитів (еозинофіли, паличкоядерні) у свинок породи п'єтрен у віці 150-ти діб і становить, відповідно, $r=0,99.3$ подальшим розвитком тварин суттєві взаємозв'язки встановлюються сегментоядерними нейтрофілами $(\mathrm{r}=0,92)$. В той час різке підвищення рівня естрадіолу в сироватці крові у тварин великої білої породи в період з 5-го по 6-й місяць істотно вплинуло на збільшення кількості незрілих паличкоядерних нейтрофілів $(\mathrm{r}=0,94)$, що підтверджує вплив жіночих статевих гормонів на рівень неспецифічної резистентності організму самок (Pierre, 2002).

Встановлено, що в організмі самок під впливом прогестерону та естрадіолу в процесі статевого дозрівання, взаємозв'язок вмісту тестостерону і морфологічного складу крові залежав від напряму продуктивності досліджуваних порід. Так у великої білої породи збільшення концентрації тестостерону до 7-го місяця постнатального розвитку включно суттєво впливало на кількість гемоглобіну $(\mathrm{r}=0,91 \ldots 0,74)$, а у породи п’єтрен схожої сили взаємоз'язки між тестостероном і гемоглобіном відмічалися у період максимального набору ваги, зумовленого генотиповим фактором, у віці 5-6 місяців і становили $\mathrm{r}=0,53 \ldots 0,90$.

Вищевикладений матеріал свідчить про те, що компоненти, які формують гематологічний гомеостаз, взаємопов'язані між собою, а їх рівень зв'язку в значній мірі залежить від рівня стероїдних та тироїдних гормонів протягом періоду статевого дозрівання та напряму продуктивності. Виявлена залежність величини коефіцієнтів кореляції від віку та фізіологічного стану свідчить про провідну роль досліджуваних гематологічних компонентів у формуванні гомеостазу на певних етапах постнатального розвитку свинок.

\section{Висновки}

1. Встановлено переважання вмісту гемоглобіну та кількості еритроцитів у крові свинок породи п'єтрен на $16 \%$ (120-та доба) і на $17 \%$ (150-та доба розвитку $(\mathrm{P}<0,05))$. Кількість лейкоцитів у свинок обох порід знижується на 150-ту добу з наступним поступовим збільшенням. У великої білої породи значення даного показнику вищі відносно породи п’єтрен і становлять - 180-та доба - 14,4\%, 210-та доба - 14\%.

2. Вікові зміни лейкоцитарної формули перебували в залежності від породної належності свинок. У великої білої з 120-ї доби відбувалося збільшення кількості паличкоядерних нейтрофілів 3 наступним різким зменшенням з 210-денного віку на 36,4\%. У свинок породи п'єтрен на 150-ту добу рівень паличкоядерних та сегментоядерних нейтрофілів знизився на $28,6 \%(\mathrm{P}<0,01)$ і 6,4\%, 3 наступним підвищенням до 210-ї доби на 30,0 і 12,6\%. Максимальна кількість лімфоцитів у свинок породи п'єтрен встановлена на 120-ту, у великої білої породи на 150-ту доби постнатального розвитку.

3. Встановлено, що кількість прогестерону у свинок великої білої породи була вищою відносно п’єтрен в усі досліджувані періоди. Максимальна різниця між ними спостерігалась на 150 добу 1,5 рази $(\mathrm{P}<0,05)$ та 210 добу 1,7 рази $(\mathrm{P}<0,01)$. Вміст естрадіолу у свинок великої білої від 120 -ї до 150 - розвитку знижується у 2,8 разів ( $<<0,001)$, п’єтрен $-1,4$ рази $(\mathrm{P}<0,05)$, а тестостерону зростає відповідно 2,1 $(\mathrm{P}<0,05)$ i 1,9 $(\mathrm{P}<0,05)$ рази. Впродовж 6 і 7-го місяців розвитку тварин концентрація тестостерону знижувалась у першого генотипу у 2 рази $(\mathrm{P}<0,05)$; у другого - 1,9 рази $(\mathrm{P}<0,01)$.

4. Вміст тироксину та трийодтироніну в сироватці крові у свинок порід п'єтрен та велика біла від 120-ї до 180-ї діб розвитку істотно зростає відповідно у 2 рази $(\mathrm{P}<0,01)$ та 2,3 (P<0,001). Концентрація тироксину у свиней великої білої породи була вищою відносно п'єтрен на 150 -ту добу на 24\%, 180-ту добу $45 \%$ та 210 -ту добу розвитку - на $56 \%(\mathrm{P}<0,05)$.

5. Встановлено істотний вплив у свинок породи п’єтрен вмісту прогестерону у 120-денному віці на кількість лімфоцитів $(\mathrm{r}=0,78)$, а в період 3 150-ї по 180-ту доби на загальну кількість лейкоцитів ( $\mathrm{r}=$ $0,60)$. У свинок великої білої породи даний гормон більш тісно корелював із вмістом лейкоцитів $(\mathrm{r}=0,73)$ лише на 120-ту добу розвитку.

6. Концентрація естрадіолу була суттєво взаємопов'язаною гранулоцитами у свинок породи п'єтрен у віці 150-ти діб ( $\mathrm{r}=0,92 \ldots 0,99)$, у тварин великої білої породи максимальний рівень кореляції був по досягненні 150-ї доби $-\mathrm{r}=0,61$ та 180 -у доби розвитку $-\mathrm{r}=$ 0,94 .

7. Збільшення концентрації тестостерону у великої білої породи до 7-го місяця постнатального розвитку суттєво вплинуло на кількість гемоглобіну $(\mathrm{r}=$ $0,91 \ldots 0,74)$, а у породи п’єтрен подібні взаємозв'язки між тестостероном і гемоглобіном відмічалися у віці 5-6 місяців і становили $\mathrm{r}=0,53 \ldots 0,90$.

Перспективи подальших досліджень. Подальші дослідження будуть проведені в напрямі вивчення впливу рівня стероїдних гормонів у свинок різних генотипів та напрямів продуктивності для розроблення ефективних способів регуляції статевого циклу для підвищення відтворювальної здатності ремонтного молодняку.

\section{References}

Antonyak, G.L. (2002). Osobly`vosti gemopoezu u tvary`n na rannix stadiyax postnatal 'nogo rozvy`tku: Dy`s. d-ra biol. nauk: 03.00.04. UAAN; Insty`tut biologiyi tvary`n. L. (in Ukrainian). 
Bianco, A.C., Salvatore, D., Gereben, B., Berry, M.J., \& Larsen, P.R. (2002). Biochemistry, cellular and molecular biology, and physiological roles of the iodothyronine selenodeiodinases. Endocr Rev., 23(1), 3889. doi: 10.1210/edrv.23.1.0455.

Davis, K., Maney, D.L., \& Maerz, J.C. (2008). The use of leukocyte profiles to measure stress in vertebrates: a review for ecologists. Functional Ecology, 22, 760 772. doi: 10.1111/j.1365-2435.2008.01467.x.

Ionov, P.S., Muhin, V.G., Fedorov, A.I., \& Sharabrin, I.G. (1952). Laboratornye issledovanija v veterinarnoj klinicheskoj diagnostike. M.: Sel'hozgiz (in Russian).

Golikov, A.N. i dr. (1991). Fiziologija sel'skohozjajstvennih zhivotnyh pod red. A. N. Golikova. 3-e izd., pererab. i dop. M.: Agropromizdat (in Russian).

Gorjachkovskij, A.M. (2005). Klinicheskaja biohimija v laboratornoj diagnostike: sprav.posob. [izd.3-e]. Odesa: Jekologija (in Russian).

Girard, J., Perdereau, D., Foufelle, F., Prip-Buus, C., \& Ferré, P. (1994). Regulation of lipogenic enzyme gene expression by nutrients and hormones. FASEB J, 8(1), 3642. https://www.ncbi.nlm.nih.gov/pubmed/7905448.

Guczol, A.V., \& Bilyavceva, V.V. (2016). Gematologichni pokazny'ky` molodnyaku svy`nej pry`zgodovuvanni BVMD Enervik. Nauk.-texn. byul. nauk.-doslid. centru biobezpeky' ta ekologichnogo kontrolyu resursiv APK. Dnipropetrovs ` k, 4(1), 32-36 (in Ukrainian).

Harris, J., \& Bird, D.J. (2000). Modulation of the fish immune system by hormones. Veterinary Immunology and Immunopathology, 77(3-4), 163-176. https:/www.ncbi.nlm.nih.gov/pubmed/11137116.

Kozlovskaja, L.V., \& Martynova, M.A. (1975). Uchebnoe posobie po klinicheskim laboratornym metodam issledovanija (s jelementami programmirovanija). M.: Medicina (in Russian).

Kondrahin, I.P., Arhipov, A.V. i dr. (2004). Metody veterinarnoj klinicheskoj laboratornoj diagnostiki: Spravochnik. M.: Kolos (in Russian).

Köhrle, J. (2000). The deiodinase family: selenoenzymes regulating thyroid hormone availability and action. Cell Mol Life Sci., 57(13-14), 1853-1863. doi: 10.1007/PL00000667.

Kranendonk, G., Hopster, H., van Eerdenburg, F., van Reenen, K., Fillerup, M., de Groot, J., Korte, M. \& Taverne, M. (2005). Evaluation of oral administration of cortisol as a model for prenatal stress in pregnant sows. American Journal of Veterinary Research, 66(5), 780 790. https://www.ncbi.nlm.nih.gov/pubmed/15934605.

Levchenko, V.I., Vlizlo, V.V., Kondraxin, I.P. ta in. (2004). Klinichna diagnosty'ka vnutrishnix xvorob tvary`n. za red. V.I. Levchenka. Bila Cerkva (in Ukrainian).

Majka, M., Janowska-Wieczorek, A., Ratajczak, J., Ehrenman, K., Pietrzkowski, Z., Kowalska, M.A., Gewirtz, A.M., Emerson, S.G., \& Ratajczak, M.Z. (2001). Numerous growth factors, cytokines, and chemokines are secreted by human CD34(+) cells, myeloblasts, erythroblasts, and megakaryoblasts and regulate normal hematopoiesis in an auto- crine/paracrine manner. Blood., 97(10), 3075-3085. https://www.ncbi.nlm.nih.gov/pubmed/11342433.

Mosin, V.A., \& Ptashkin, V.A. (1984). Vlijanie koncentracii tireoidnyh gormonov na gazojenergeticheskij obmen $\mathrm{u}$ jagnjat. The effect of the concentration of thyroid hormones on gas and energy metabolism in lambs. Bjul. VNII fiziologii,biohimii i pitanija sel'skohozjajstvennyh zhivotnyh. Borovsk, 24-27 (in Russian)

Pierre, R.V. (2002). Peripheral blood film review. The demise of the eyecount leukocyte differential. Clin Lab Med., 22(1), 279-297. https://www.ncbi.nlm.nih.gov/ pubmed/11933579.

Rassolov, S.N., Poljakov, A.D., Kazakova, M.A., \& Kuznecov, A.Ju. (2014). Vlijanie preparatov joda i selena v komplekse s probiotikom na produktivnost' i morfologicheskij sostav krovi remontnyh svinok. Uspehi sovremennogo estestvoznanija, 11(3), 44-46 (in Russian).

Salak-Johnson, J.L., McGlone, J.J., \& Norman, R.L. (1996). In vivo glucocorticoid effects on porcine natural killer cell activity and circulating leukocytes. J Anim Sci., 74(3), 584-592. https://www.ncbi.nlm.nih.gov/ pubmed/8707714.

Salomatin, V.V., Zlepkin, V.A., \& Budtuev, O.V. (2010). Vlijanie treonina i fermentativnyh preparatov na morfologicheskij i biohimicheskij sostav krovi u podopytnyh svinej na otkorme. Novye napravlenija $v$ reshenii problem APK na osnove sovremennyh resursosberegajushih innovacionnyh tehnologij: materialy mezhdunar. nauch.-prakt. konf. Volgograd, 1, 215218 (in Russian).

Simonjan, G.A., \& Hisamutdinov, F.F. (1995). Veterinarija gematologija. M.: Kolos (in Russian).

Pinto, A., Juniper, D.T., Sanil, M., Morgan, L., Clark, L., Sies, H., Rayman, M.P., \& Steinbrenner, H. (2012). Supranutritional selenium induces alterations in molecular targets related to energy metabolism in skeletal muscle and visceral adipose tissue of pigs. J Inorg Biochem. 114, 47-54. doi: 10.1016/j.jinorgbio.2012.04.011.

Nandi, S., \& Rani, R. (2015). A study of total leukocyte count in different phases of menstrual cycle. National Journal of Physiology, Pharmacy \& Pharmacology, 5(2), 108-110. doi: 10.5455/njppp.2015.5.260920141.

Vognivenko, L.P., Novikova, N.V., Arxangel`s 'ka, M.V., Papakina, N.S., Kushnerenko, V.G., Lisna, T.M., \& Ferens, T.O. (2015). Zv'yazok mizh bioximichny`my` pokazny`kamy` krovi svy`nej riznoyi stresostijkosti iz yix vidgodivel'ny`my` yakostyamy` v umovax plemzavodu ZAT "Fridom farm bekon". Naukovij visnik “Askanija-Nova”, 8. 183-191 (in Ukrainian).

Whittle, W.L., Patel, F.A., Alfaidy, N., Holloway, A.C., Fraser, M., Gyomorey, S., Lye, S.J., Gibb, W., \& Challis, J.R. (2001). Glucocorticoid Regulation of Human and Ovine Parturition: The Relationship Between Fetal Hypothalamic-Pituitary-Adrenal Axis Activation and Intrauterine Prostaglandin Production. Biology of Reproduction, 64(4), 1019-1032. https://www.ncbi.nlm.nih.gov/pubmed/11259246. 